\title{
Public Health Insurance Reform And Women's Labor Supply Decisions
}

Akinori Tomohara, (E-mail: jujodai@yahoo.com), City University of New York Ho Jin Lee, (Email: ho.j.lee@us.pwc.com), University of California, Irvine

\begin{abstract}
The literature has explored the effects of welfare policy reforms on women's labor supply. However, a comprehensive analysis has not been conducted regarding the effects of individual policy instruments in public assistance programs. This paper examines whether policy instruments in the public health insurance program affect women's labor supply decisions, specifically, after we control for the effects of policy instruments in the welfare program. The results indicate that, on average, public health insurance policy instruments did not affect women's labor supply. Our analysis implies that, regarding the recent reform on public assistance programs, the crowd-out of private health insurance for public health insurance is less likely to arise via a reduced labor supply channel.
\end{abstract}

\section{INTRODUCTION}

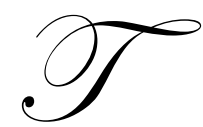

he United States dramatically changed public assistance policies during the 1990s. The passing of the Personal Responsibility and Work Opportunity Reconciliation Act (PRWORA) converted the welfare program, Aid to Families with Dependent Children (AFDC), to Temporary Assistance for Needy Families (TANF). While government control of AFDC was relatively centralized, TANF gives states increased freedom to tailor welfare policies. Similarly, the provision of public health insurance has been a state initiative since the early 1990s. The State Children's Health Insurance Program (SCHIP) was enacted as part of the Balanced Budget Act of 1997. SCHIP expanded public health insurance coverage to children who did not previously qualify for Medicaid. Several states began to offer health insurance to working adults in the mid-1990s.

This paper examines whether policy instruments in public assistance programs affect women's labor supply decisions. The literature has explored the effects of welfare reforms on women's labor supply (Moffitt, 1999; McKernan et. al., 2000; Schoeni and Blank, 2000; Meyer and Rosenbaum, 2001; O'Neill and Hill, 2001; Fender et al., 2002; Grogger, 2003; see also the survey by Moffitt, 2001). Previous works consider the effects of a welfare reform using selected policy instruments. While the examination of individual instruments is of increasing research interest, a comprehensive analysis regarding the effectiveness of instruments in public assistance programs does not exist (Moffitt, 2001; Danielson and Klerman, 2004).

In an attempt to fill this gap, we study the effects of various policy instruments on women's labor supply decisions. Specifically, our analysis examines the effects of public health insurance policy instruments after controlling for the effects of welfare policy instruments. The analysis relates two branches of the literature. The first is the effects of welfare reforms on women's labor supply. The second is the effects of public health insurance reforms on women's labor supply. Several articles study possible effects of Medicaid expansions for children on women's labor supply decisions (see the survey by Gruber and Madrian, 2002). Very few attempts have been made at analyzing the effects of both welfare and public health insurance programs together on women's labor supply decisions.

We conduct a comprehensive analysis on the relationships between policy instruments in public assistance programs and women's labor supply. Our analysis shows that, on average, policy instruments in the public health insurance program did not affect women's labor supply, once we control for the effects of policy instruments in the 
welfare program. The results call for further investigation regarding the crowd-out of private health insurance coverage for public health insurance coverage. The literature shows the possibility of crowd-out occurring during the late $1980 \mathrm{~s}$ and the early $1990 \mathrm{~s} .{ }^{1}$ However, our analysis implies that crowd-out is less likely to arise as the result of the recent public assistance program reforms via a reduced labor supply channel.

\section{BACKGROUND ${ }^{2}$}

AFDC was implemented under the Social Security Act of 1935 . This program provided cash assistance to needy families with children. States created and administered AFDC programs in accordance with federal regulations and guidelines. Since 1962, states have been allowed to implement changes to their individual welfare programs. States were allowed to deviate from the federal regulations by obtaining waivers from the Department of Health and Human Services. Examples of state specific stipulations include family caps, time limits on benefits, and benefits sanctions on welfare recipients who do not comply with job-related activity requirements. In 1996, the PRWORA replaced AFDC with TANF. States were given complete freedom in determining and administering their own welfare programs. By 1998, all states had implemented a TANF program.

AFDC participants, in addition to receiving cash handouts, were also given Medicaid coverage and food stamps as part of the benefits package. Medicaid was established to cover AFDC participants with the Social Security Amendments of 1965 . However, the link between AFDC and Medicaid was severed through various legislative actions in the mid-1980s. The federal government expanded Medicaid income eligibility requirements beyond AFDC income eligibility thresholds to provide health insurance coverage to poor pregnant women and children (Yelowitz, 1995). Starting in the mid-1990s, states began to institute either separate or state specific health insurance programs, as was typical under TANF implementation. By 1996, 18 states submitted Medicaid waivers. These 18 states expanded eligibility to a larger population of children. In 1996, nine states (California, Colorado, Connecticut, Delaware, Massachusetts, New Jersey, New York, Pennsylvania, and Virginia) instituted separate, state funded health insurance programs. As part of the movement toward state initiated healthcare programs, the State Children's Health Insurance Program (SCHIP) was enacted as part of the Balanced Budget Act of 1997. States were given flexibility in establishing state specific SCHIP. States can expand their Medicaid program (M-SCHIP), establish a separate state program (S-SCHIP), or establish a combination of the two (COMBO). ${ }^{3}$ In additional to expanding healthcare benefits for children, several states employed either Medicaid waivers and/or state funds to offer health insurance to working adults in the mid-1990s. In 1996, eight states (Delaware, Hawaii, Minnesota, Oregon, Rhode Island, Tennessee, Vermont, and Washington) offered some form of public health insurance to working adults. In 2000, 15 states and the District of Columbia offered some form of public health insurance to adults in poor families.

In sum, we observe that both welfare and public health insurance programs began to vary at the state level in the mid-1980s. All states obtained autonomy in designing their welfare and public health insurance programs by the mid-1990s.

\section{DATA}

We use the March Annual Demographic files of the Current Population Survey (CPS) covering the years of 1996 to 2000. The CPS is a nationally representative repeated cross-section survey that contains an average of 60,000 households per year. The CPS provides national data on public assistance for individual families as well as detailed demographic characteristics. The survey is commonly used in the literature (e.g., Moffitt, 1999; O'Neill and Hill,

\footnotetext{
${ }^{1}$ Several works study the effects of Medicaid expansions on the substitution of public health insurance for private health insurance. The literature indicates there is a possibility that crowd-out occurred during the late 1980s and the early 1990s (Cutler and Gruber, 1996; Shore-Sheppard, 2000; Blumberg et al., 2000; Ham and Shore-Sheppard, 2001; Card and Shore-Sheppard, 2002). Kronick and Gilmer (2001) and LoSasso and Buchmueller (2002) find similar results when considering public health insurance expansions during the more recent periods of the late 1990s and the early 2000 s.

${ }^{2}$ Moffitt (2001) presents detailed history of AFDC/TANF. Blank and Ellwood (2001) summarizes recent changes in welfare, food stamp, and public health insurance programs. Gruber (2000) provides a detailed account of the Medicaid program. Refer to Cutler and Gruber (2001) for public health insurance policies during the 1990s.

${ }^{3}$ In March of 2000, 15 states created an S-SCHIP, 19 states had an M-SCHIP, and 17 states had a COMBO. As of April of 2002, Maryland, South Dakota, and Texas had switched to a COMBO, and West Virginia had dropped M-SCHIP.
} 
2000; Schoeni and Blank, 2000; Grogger, 2003). We consider the time period after which state autonomy in designing welfare programs was complete. Since states have been autonomous in designing welfare and public health insurance programs, there have been variations in employed policy instruments.

Our analysis uses the full sample of women as in Moffitt (1999) and Schoeni and Blank (2000). This results in a sample containing 185,682 women, ages 16-54. Table 1 presents the summary statistics of our sample. There are a couple of observations worthy of note. First, the women's labor force participation rate is stable at approximately 77\% each year. Second, between 1996 and 2000, we observe a decrease in welfare participation rates. Some works restrict their analysis to a sub-sample of single mothers, since married mothers and single non-mothers are not eligible for the welfare program. However, there is evidence that welfare policies affect fertility and marital decisions. Additionally, Grogger (2003) says that restricting the sample may introduce sample selection bias (p. 395). Selecting a full sample of women avoids this problem.

Information on policy instruments is extracted from various sources (see Table 2). Our analysis considers two instruments in public health insurance programs. One is an indicator for public health insurance offerings to working adults. The other is the monetary value of public health insurance benefits. The latter is the so called public health insurance notch (Yelowitz, 1995; Meyer and Rosenbaum, 2000). We use the maximum of either the Medicaid notch or the SCHIP notch as the public health insurance notch.

The analysis controls for the effects of nine policy instruments in welfare programs. The nine policy instruments are activity requirements, activity sanctions, diversion programs, time limits on benefits, family caps, welfare guarantees, earned income disregards, benefits reduction rates, and income eligibility tests. ${ }^{4}$ Brief explanations for each policy instrument are as follows. States provide various job training programs to welfare recipients in order to promote working. "Activity requirements" measure the degree to which each state makes such efforts. Welfare recipients must participate in these programs to maintain their welfare benefits. Otherwise, their benefits are discontinued. "Activity sanctions" measure how strict states are in sanctioning those who do not satisfy the requirements. Several states established a diversion program throughout the sample period. ${ }^{5}$ These programs aim to divert either eligible applicants and/or current recipients from welfare participation via benefits such as cash payments. "Diversion programs" measure the effectiveness. We also include an indicator for time limit policies on receiving welfare benefits. Most states set time limits on receiving benefits to reduce the duration of welfare participation. The remaining variables capture the state's level of generosity with respect to welfare benefits. "Family caps" are sets of policies that limit the marginal increase in welfare benefits for families that conceive an additional child while receiving aid. "Welfare guarantees" are the amount of welfare benefits for a non-working welfare participant. "A benefits reduction rate" is a rate at which welfare benefits decrease as earned income increases. "Earned income disregards" calculate financial incentives for non-working welfare participants who start and maintain full-time employment for one year at a state minimum wage rate. Finally, each state implements different income eligibility tests for welfare benefits.

Regarding the trends of the policy instruments, states became more generous in offering public health insurance during our sample period. The public health insurance notch increased drastically. This large increase is due to increased income eligibility for public health insurance after SCHIP implementation. Several states also instituted a public health insurance program for working adults during the sample period. Regarding the welfare program, there is trade-off among policy instruments. With the introduction of TANF, states became more aggressive in activity sanctioning, but the number of activity requirements remained fairly constant. The real value of earned income disregards increased by $58 \%$ and income eligibility threshold fell by almost half. However, the real value of welfare guarantee fell and benefits reduction rates increased. The latter changes make the welfare program less attractive. The former changes make the welfare program more attractive.

\footnotetext{
${ }^{4}$ Policy instruments such as welfare guarantees, earned income disregards, benefits reduction rates, income eligibility tests, and time limits, are often a main focus in the literature. The AFDC literature examines the effects of the AFDC guarantees and benefits reduction rates (Hoynes, 1997). Moffitt (1999) uses welfare guarantees for a family of three, earnings disregards, lifetime limits, family caps, and sanctions.

${ }^{5}$ For example, Florida established a diversion program in 1997, Connecticut in 1999, and California in 2003.
} 


\section{RESULTS OF THE ANALYSIS}

We use a probit model to examine the effects of public health insurance instruments on women's labor supply decisions. In addition to the nine welfare program instruments described above, our model includes additional policy instruments that could affect women's labor supply decisions. They are annual salary level earned at the state's minimum wage rates, the state and federal earned income tax credits, and an indicator for Medically Needy programs. ${ }^{6}$ These variables control for the effects of the earned income tax credit and minimum wage policy reforms during the sample period. Our analysis also controls for demographic differences such as age, education, and race. Furthermore, we incorporate unobservable factors that could be related to women's labor supply decisions and/or a policy endogeneity problem. Year fixed effects are time varying elements that affect all states in a given year. State fixed effects are time invariant elements that differ across states. Different labor market conditions over time and across states are captured by four indicators: a state level unemployment rate, a lag of the state unemployment rate, an employment growth rate, and a lag of the employment growth rate. The model may yield inconsistent estimates if time-varying factors across states affect the timing of the policy instruments used in each state. Previous works suggest adding state-specific trends (CEA, 1997, 1999; Moffitt, 1999; Schoeni and Blank, 2000; Grogger, 2003; Ziliak et al., 2000) to incorporate such unobservable factors. Our model uses linear state-specific trends as in the literature.

Table 3 presents the results of the analysis. Public health insurance program instruments, on average, did not affect women's labor supply decisions. The results are not surprising. Specifically, the effects of the public health insurance notch on work decision are theoretically ambiguous due to both substitution and income effects. Some women may have decreased labor supply in order to become eligible for public health insurance. However, others may have increased their labor supply if they previously chose not to work or chose to work reduced hours in order to be eligible for public health insurance. With a higher public health insurance notch, the family can now increase their income and still maintain public health insurance coverage.

Only three of the welfare program policy instruments are found to affect women's labor supply. Employment increases with additional job-related activities required for the welfare program. The activities help women to acquire the skills necessary for job hunting. Concerning recent financial incentive instruments, increased benefit reduction rates encouraged women to work, but increased earned income disregards discouraged women from working. These results are consistent with Moffitt (1997), who suggests a 100\% benefit reduction rate and no earned income disregards in order to promote working.

Remaining policy instruments did not affect women's labor supply decisions at statistically significant levels. The goal of some policy instruments was to promote working. However, in some cases, the governments' objectives did not seem to be satisfied. For example, a diversion program provides a financial incentive for non-working welfare participants to start working. Yet, current working non-welfare participants may have reduced their work in order to obtain the benefits. The unintended impact is due to changes in opportunity cost faced by non-welfare participants. The two counterbalancing effects could have decreased the precision of the estimate.

We examine the robustness of our findings using alternative specifications. The further analysis examines public health insurance notches for an infant (age less than 1), a 7-year-old child, and a 17-year-old child. Overall, female labor supply is not sensitive to any particular age group notches. We also control for states' business cycle effects using the current and lagged per capita real disposable income and the current and lagged real value of the Gross State Product. Previous results remain robust in the presence of additional control variables or under alternative specifications.

We conduct a comprehensive analysis of the effects of public assistance program policy instruments. This is because the literature using selected policy instruments provides mixed results. Some works do not find evidence that Medicaid expansions affected single mothers' labor supply (Ham and Shore-Sheppard, 2000; Meyer and Rosenbaum, 2000; Meyer and Rosenbaum, 2001). Other works show that Medicaid expansions decreased the labor supply of

\footnotetext{
${ }^{6}$ Under the Medically Needy program, states can extend Medicaid coverage to individuals who are in families with income above the Medicaid income threshold.
} 
single mothers (Blank, 1989; Winkler, 1991; Moffitt and Wolfe, 1992; Yelowitz, 1995). Our analysis shows that, on average, public health insurance policy instruments did not affect women's labor supply, once we control for the effects of welfare policy instruments. The results provide governments with useful guidance regarding how to coordinate several public assistance program policy instruments. The results also provide policy insight into the crowd-out of private health insurance for public health insurance possibly resulting from the recent public assistance program reforms. Crowd-out can result from reduced labor supply. If some women decreased their labor supply in response to public health insurance program reforms, then the goals of the reform were not achieved. Families may choose to drop their children's private health insurance in lieu of public coverage via reduced income. Our results imply that crowd-out via reduced labor supply is less likely to arise, since we do not find any evidence of women changing their labor supply in response to public health insurance policy changes.

\section{CONCLUSION}

This paper examines whether policy instruments in the public health insurance program affect women's labor supply decisions, specifically, after controlling for the effects of welfare policy instruments. We consider the time period after which state autonomy in designing public assistance programs was complete. Since states have been autonomous in designing welfare and public health insurance programs, there have been variations in the policy instruments employed.

Our analysis shows that, on average, policy instruments in the public health insurance program did not affect women's labor supply, once we control for the effects of the welfare program policy instruments. The results call for further investigation in order to thoroughly assess the crowd-out of private health insurance coverage for public health insurance coverage. The literature shows the possibility of crowd-out during the late 1980s and the early 1990s. Our analysis implies that crowd-out is less likely to result from the recent public assistance program reforms via a reduced labor supply channel.

Our analytical framework is applicable to other situations. We consider all women to avoid sample bias. Nonetheless, an analysis of a sub-sample could be of interest. The use of a sub-sample helps avoid parameter heterogeneity, as alluded to by Grogger $(2002,2003)$. If the degree to which welfare policy affects fertility and marital decisions is negligible, the current empirical analysis may underestimate the effects of policy instruments (i.e., parameter heterogeneity is a more serious issue than sample bias). Studying a sub-category of single women extends the current study to address these issues. Our current analysis provides aggregate impacts of policy instruments on female labor supply. The effects of public assistance programs may vary among different socio-economic groups. Using various sub-samples and comparing results would provide better understanding of the policy effects and their implication beyond what was already found in this paper. These topics represent potential future lines of research.

\section{ACKNOWLEDGMENTS}

We would like to thank Janet Currie, Jonathan Gruber, and Aaron Yelowitz for providing various datasets and David Neumark and Bill Wascher for providing minimum wage data. We are also grateful to Marigee Bacolod, David Brownstone, and Molly Sherlock for their suggestions and comments. Specifically, the second author would like to thank Sarah Senesky for her countless hours of help as a thesis advisor. The first author appreciates financial support from the Research Foundation of the City University of New York. All views and errors are ours. 
Table 1: Summary Statistics

\begin{tabular}{|c|c|c|}
\hline Variable & Mean & Std. Dev. \\
\hline \multicolumn{3}{|l|}{$\begin{array}{rll} & \text { All Years } \\
\end{array}$} \\
\hline Work & 0.770 & 0.420 \\
\hline Welfare Use & 0.034 & 0.180 \\
\hline \multicolumn{3}{|l|}{1996} \\
\hline Work & 0.761 & 0.425 \\
\hline Welfare Use & 0.049 & 0.215 \\
\hline \multicolumn{3}{|l|}{1997} \\
\hline Work & 0.768 & 0.422 \\
\hline Welfare Use & 0.038 & 0.191 \\
\hline \multicolumn{3}{|l|}{1998} \\
\hline Work & 0.770 & 0.421 \\
\hline Welfare Use & 0.031 & 0.173 \\
\hline \multicolumn{3}{|l|}{1999} \\
\hline Work & 0.778 & 0.416 \\
\hline Welfare Use & 0.027 & 0.162 \\
\hline \multicolumn{3}{|l|}{2000} \\
\hline Work & 0.775 & 0.418 \\
\hline Welfare Use & 0.023 & 0.149 \\
\hline & Fraction & Std. Dev. \\
\hline \multicolumn{3}{|l|}{ Age Categories } \\
\hline Ages $16-25$ & 0.233 & 0.423 \\
\hline Ages 26-34 & 0.234 & 0.423 \\
\hline Ages $35-44$ & 0.293 & 0.455 \\
\hline Ages $45-54$ & 0.240 & 0.427 \\
\hline \multicolumn{3}{|l|}{ Race } \\
\hline White & 0.837 & 0.369 \\
\hline Black & 0.109 & 0.311 \\
\hline Asian, Pacific Islander & 0.040 & 0.197 \\
\hline American Indian, Eskimo & 0.014 & 0.117 \\
\hline \multicolumn{3}{|l|}{$\begin{array}{ll}\text { Education } \\
\end{array}$} \\
\hline Less than a High School Diploma & 0.183 & 0.387 \\
\hline High School Graduate & 0.303 & 0.459 \\
\hline Some College or an Associates Degree & 0.291 & 0.465 \\
\hline Four Year College Graduate & 0.162 & 0.369 \\
\hline Masters, Professional, Ph.D. & 0.061 & 0.239 \\
\hline Age of the Youngest Child in the Family given that a child exists & 7.012 & 5.182 \\
\hline Total Number of Children in the Family given that a child exists & 1.905 & 0.968 \\
\hline Number of Observations & 185,682 & \\
\hline
\end{tabular}


Table 2: Data Sources

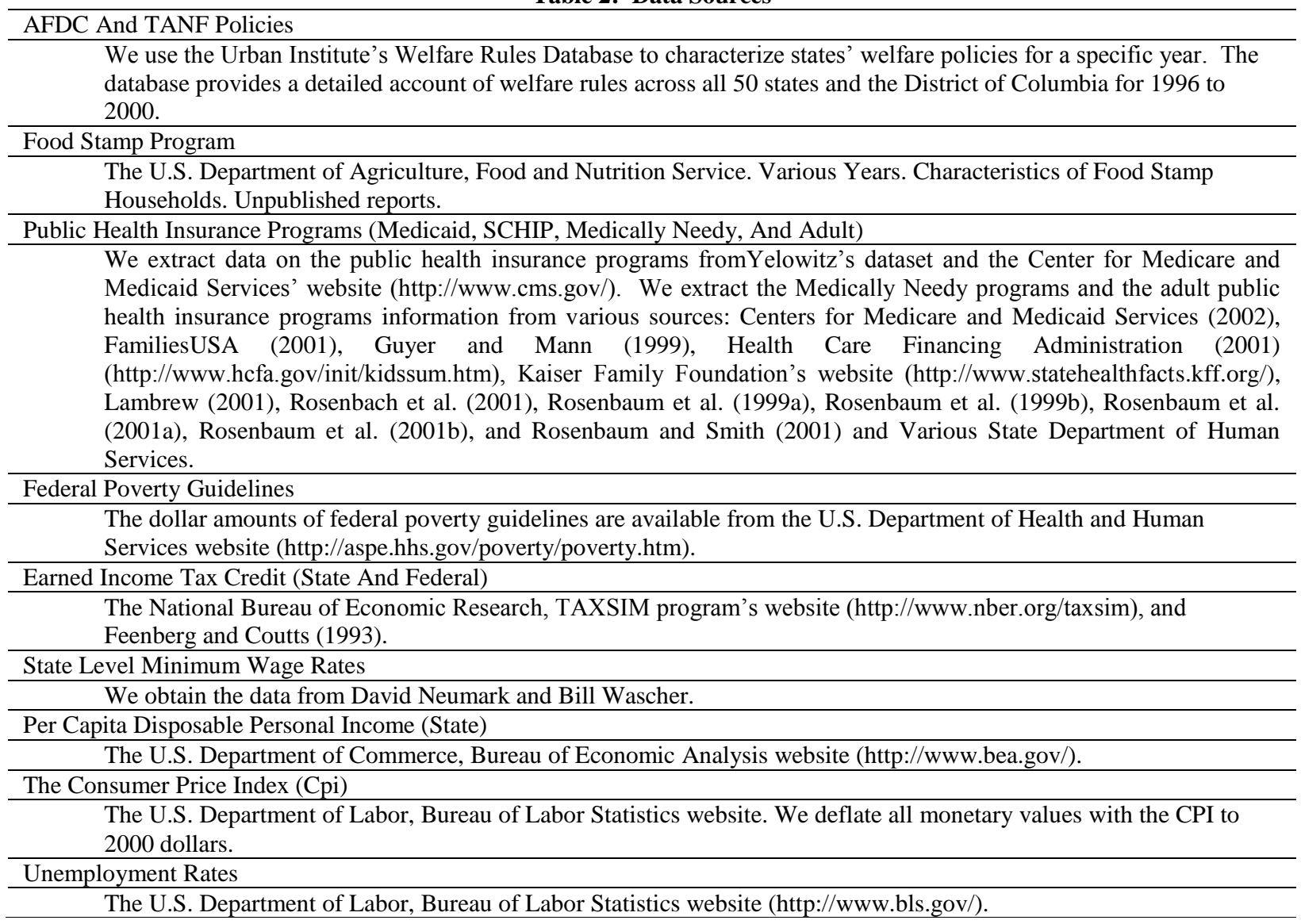


Table 3: The Results Of The Analysis

\begin{tabular}{|c|c|c|c|}
\hline & (1) & (2) & (3) \\
\hline \multirow[t]{2}{*}{ Public Health Insurance Notches } & 0.000 & 0.000 & 0.000 \\
\hline & $(0.000)$ & $(0.000)$ & $(0.000)$ \\
\hline \multirow[t]{2}{*}{ Working Adult Public Health Insurance Programs (Indicator) } & 0.022 & 0.019 & 0.018 \\
\hline & $(0.021)$ & $(0.020)$ & $(0.020)$ \\
\hline \multirow{2}{*}{$\begin{array}{l}\text { Activity Sanctions (higher number indicates more sever } \\
\text { sanctions) }\end{array}$} & 0.019 & 0.02 & 0.021 \\
\hline & $(0.013)$ & $(0.013)$ & $(0.013)^{*}$ \\
\hline \multirow{2}{*}{$\begin{array}{l}\text { Activity Requirements (higher number indicates more } \\
\text { allowable activities) }\end{array}$} & 0.009 & 0.008 & 0.008 \\
\hline & $(0.003) * *$ & $(0.003)^{* *}$ & $(0.003) * *$ \\
\hline \multirow{2}{*}{$\begin{array}{l}\text { Diversion Programs (higher number indicates more generous } \\
\text { program) }\end{array}$} & 0.008 & 0.007 & 0.007 \\
\hline & $(.005)^{*}$ & $(0.005)$ & $(0.005)$ \\
\hline \multirow[t]{2}{*}{ Time Limit on Welfare Benefits (Indicator) } & 0.003 & 0.008 & 0.006 \\
\hline & $(0.014)$ & $(0.014)$ & $(0.014)$ \\
\hline \multirow[t]{2}{*}{ Real Value of Welfare Benefits (1000s) } & -0.009 & -0.021 & -0.013 \\
\hline & $(0.015)$ & $(0.014)$ & $(0.014)$ \\
\hline \multirow{2}{*}{ Benefits Reduction Rates } & 0.001 & & 0.001 \\
\hline & $(0.000)^{* * *}$ & & $(0.000)^{* *}$ \\
\hline \multirow[t]{2}{*}{ Earned Income Disregards (1000s) } & & -0.01 & -0.008 \\
\hline & & $(0.004)^{* * * *}$ & $(0.004)^{* *}$ \\
\hline \multirow{2}{*}{$\begin{array}{l}\text { Family Caps (higher number indicates more aggressive } \\
\text { policy) }\end{array}$} & -0.001 & 0.006 & 0.006 \\
\hline & $(.008)$ & $(.009)$ & $(.009)$ \\
\hline \multirow[t]{2}{*}{ Income Tests (the percentage of poverty guidelines) } & 0.000 & 0.000 & 0.000 \\
\hline & $(0.000)$ & $(0.000)$ & $(0.000)$ \\
\hline Observations & 185,682 & 185,682 & 185,682 \\
\hline \multicolumn{4}{|c|}{$\begin{array}{l}\text { Note: The standard errors in parentheses are corrected for clustering within state-year cells as in Moulton (1986). The first } \\
\text { model excludes earned income disregards. The second model excludes benefit reduction rates. The two instruments } \\
\text { measure a similar effect (i.e., financial incentives to promote work) and are correlated. The last model includes both } \\
\text { instruments. }\end{array}$} \\
\hline \multicolumn{4}{|c|}{$\begin{array}{l}\text { All regressions include age, education, and race dummies as well as time and state dummies and state specific trends. We } \\
\text { also include an unemployment rate and its lag, an employment growth rate and its lag, the real value of the annual salary } \\
\text { calculated at the minimum wage rate, the real value of the state and federal earned income tax credits for a family of three, } \\
\text { and an indicator for the Medically Needy Program. }\end{array}$} \\
\hline
\end{tabular}

\section{REFERENCES}

1. Blank, R. 1989. The Effect of Medical Need and Medicaid on Medicaid on AFDC Participation. Journal of Human Resources, XXIV: 54-87.

2. Blank, R. and D. Ellwood. 2001. The Clinton Legacy for America's Poor. National Bureau of Economic Research Working Paper 8437.

3. Blumberg, L.J., L. Dubay, and S.A. Norton. 2000. Did the Medicaid Expansions for Children Displace Private Insurance? An Analysis Using the SIPP. Journal of Health Economics 19(1): 33-60.

4. Card, D. and L.D. Shore-Sheppard. 2002. Using Discontinuous Eligibility Rules to Identify the Effects of Federal Medicaid Expansions. National Bureau of Economic Research Working Paper 9058.

5. Centers for Medicare and Medicaid Services. 2002. The State Children's Health Insurance Program Annual Enrollment Report. Washington D.C.

6. Council of Economic Advisors. 1997. Explaining the Decline in Welfare Receipt, 1993-1996. Technical Report.

7. Council of Economic Advisors. 1999. The Effects of Welfare Policy and the Economic Expansion on Welfare Caseload: An Update. Technical Report.

8. Cutler, D. and J. Gruber. 2001. Health Policy in the Clinton Era: Once Bitten, Twice Shy. National Bureau of Economic Research Working paper 8455.

9. Danielson, C. and J.A., Klerman. 2004. Why did Welfare Caseload Decline? Mimeo Families USA. 2001. 
10. Expanding Coverage for Low-Income Parents: An Action Kit For Advocates. Unpublished Report. Washington D.C.: FamiliesUSA.

11. Feenberg, D. R. and E. Coutts. 1993. An Introduction to the TAXSIM Model. Journal of Policy Analysis and Management 12: 189-194.

12. Fender, L., S. McKernan, and J. Bernstein. 2002. Linking State TANF and Related Policies to Outcomes: Preliminary Typologies and Analysis. Mimeo, Urban Institute.

13. Grogger, J., 2003. The Effects of Time Limits, the EITC, and Other Policy Changes on Welfare Use, Work, and Income Among Female-Headed Families. Review of Economics and Statistics 85(2): 394-408.

14. Gruber, J. 2000. Medicaid. National Bureau of Economic Research Working Paper 7829.

15. Gruber, J. and B.C. Madrian. 2002. Health Insurance, Labor Supply, and Job Mobility: A Critical Review of the Literature. National Bureau of Economic Research Working Paper 8817.

16. Guyer, J. and C. Mann. 1999. Employed But Not Insured: A State-by-State Analysis of the Number of LowIncome Working Parents Who Lack Health Insurance. Washington D.C.: Center on Budget and Policy Priorities.

17. Ham, J. C. and L. D. Shore-Sheppard. 2001. The Impact of Public Health Insurance on Labor Market Transitions. Williams College Working Paper.

18. Health Care Financing Administration (HCFA). 2001. State Children's Health Insurance Program (SCHIP) Aggregate Enrollment Statistics for the 50 States and the District of Columbia for Federal Fiscal Years (FFY) 2000 and 1999. Unpublished Chart. Washington D.C.: HCFA.

19. Hoynes, H. 1997. Work, Welfare, and Family Structure: What Have We Learned? In Fiscal Policy: Lessons from Economic Research. Ed. A. Auerbach. Cambridge: MIT Press.

20. Kronick, R. and T. Gilmer. 2002. Insuring Low-Income Adults: Does Public Coverage Crowd Out Private? Health Affairs 21: 225-239.

21. Lambrew, J. 2001. Section 1115 Waivers in Medicaid and the State Children's Health Insurance Program: An Overview. The Kaiser Commission on Medicaid and the Uninsured. Kaiser Family Foundation.

22. Lo Sasso, A. and T. Buchmueller. 2002. The Effect of the State Children's Health Insurance Program on Health Insurance Coverage. National Bureau of Economic Research Working Paper 9405.

23. McKernan, S., Lerman, R., Pindus, N., and Valente, J., 2000, The Relationship Between Metropolitan and Non-Metropolitan Locations, Changing Welfare Policies, and the Employment of Single Mothers. Mimeo, Urban Institute.

24. Meyer, B. D. and D.T. Rosenbaum. 2000. Medicaid, Private Health Insurance, and the Labor Supply of Single Mothers. Unpublished Paper, Northwestern University.

25. Meyer, B. D. and D.T. Rosenbaum. 2001. Welfare, the Earned Income Tax Credit, and the Labor Supply of Single Mothers. Quarterly Journal of Economics 116: 1063-1114.

26. Moffitt, R. 1997. Comment on Work, Welfare, and Family Structure: What Have We Learned? In Fiscal Policy: Lessons from Economic Research. ed. A. Auerbach. Cambridge: MIT Press.

27. Moffitt, R. 1999. The Effect of Pre-PRWORA Waivers on AFDC Caseloads and Female Earnings, Income, and Labor Force Behavior. In Economic Conditions and Welfare Reform. ed. S. Danziger. Kalamazoo: Upjohn Institute.

28. Moffitt, R. 2001. The Temporary Assistance for Needy Families Program. National Bureau of Economic Research Working Paper 8749.

29. Moffitt, R. and B. Wolfe. 1992. The Effect of the Medicaid Program on Welfare Participation and Labor Supply. Review of Economics and Statistics LXXIV: 615-26.

30. Moulton, B. 1986. Random Group Effects and the Precision of Regression Estimates. Journal of Econometrics 32: 385-397.

31. O’Neill, J. and M.A. Hill. 2001. Gaining Ground? Measuring the Impact of Welfare Reform on Welfare and Work. New York: Manhattan Institute.

32. Rosenbach, M., M. Ellwood, J. Czajka, C. Irvin, W. Coupe, and B. Quinn. 2001. Implementation of the State Children's Health Insurance Program: Momentum Is Increasing After a Modest Start. Mathematica Policy Research, Inc. MPR Reference \# 8644-102.

33. Rosenbaum, S., J. Darnell, P. Seliger, and L. Simon. 1999a. Section 1115 Medicaid Waivers: Charting a Path for Medicaid Managed Care Reform. Access to Health Care: Promises and Prospects for Low-Income Americans. ed. M. L. Blanton, R. 
34. Rosenbaum, S. and D. Roby. 1999b. An Analysis of Implementation Issues Relating to CHIP Cost-Sharing Provisions for Certain Targeted Low Income Children. Prepared for the Health Care Financing Administration and the Health Resources and Services Administration. Center for Health Services Research and Policy. George Washington University, Washington DC.

35. Rosenbaum, S., M. Proser, A. Schneider, and C. Sonosky. 2001a. Room to Grow: Promoting Child Development Through Medicaid and CHIP. Center for Health Services Research and Policy, George Washington University, Washington DC.

36. Rosenbaum, S., K. Shaw, and C. Sonosky. 2001b. Policy Brief \#3: Managed Care Purchasing under SCHIP: A Nationwide Analysis of Freestanding SCHIP Contracts. Issue Brief. Center for Health Services Research and Policy, George Washington University, Washington DC.

37. Schoeni, R. and R. Blank. 2000. What Has Welfare Reform Accomplished? Impact on Welfare Participation, Employment, Income, Poverty, and Family Structure. National Bureau of Economic Research Working Paper 7627.

38. Shore-Sheppard, D. L. 2000. The Effect of Expanding Medicaid Eligibility on the Distribution of Children's Health Insurance Coverage. Industrial and Labor Relations Review 54(1): 59-77.

39. Winkler, A. 1991. The Incentive Effects of Medicaid on Women's Labor Supply. Journal of Human Resources XXVI: 308-37.

40. Yelowitz, A. 1995. The Medicaid Notch, Labor Supply, and Welfare Participation: Evidence from Eligibility Expansion. Quarterly Journal of Economics 105: 909-940.

41. Ziliak, J.P., D.N. Figlio, E.E. Davis, and L.S. Connolly. 2000. Accounting for the Decline in AFDC Caseloads: Welfare Reform or Economic Growth?, Journal of Human Resources 35: 570-86. 